\title{
ПРЯМЕ КИРИЛИЧНО-ЛАТИНИЧНЕ ТРАНСКОДУВАННЯ: ДОСВІД ПОСТСОЦІАЛІСТИЧНИХ КРАЇН
}

Урамках повернення України в європейський простір з кожним роком зростає необхідність коректного відтворення українських власних назв засобами латинського алфавіту. У цій роботі описано основні недоліки офіційного стандарту украӥнсько-латинської транслітерації КМУ 2010, досліджено досвід переходу з кириличного до латиничного письма постсоціалістичних країн, зокрема Румунії, Молдови, Сербї, Туркменістану, Узбекистану, Казахстану й Азербайджкану, визначено найбільш спірні літери й порівняно результати із КМУ 2010. Удослідженні використано порівняльний і описовий методи.

Ключові слова: кирилиия, латиниия, транскодування, транслітерація, алфавіт, графіка, голосний, приголосний.

Minkovska I.I. Direct Cyrillic-Latin Transcoding: Experience of Post-Socialist Countries. As part of the return of Ukraine to the European space, with each passing year, the need for the correct reproduction of Ukrainian proper names - names, surnames, company names, toponyms, urbanonyms, national-cultural processes, etc. - by means of the Latin alphabet is growing. These and similar processes motivate the relevance of linguistic research in the field of transcoding various languages.

As a main goal and tasks in the work the main shortcomings of the KMU 2010 official standard of the Ukrainian-Latin transliteration was described, the transition from the Cyrillic to Latin writing of the post-Socialist countries, particularly Romania, Moldova, Serbia, Turkmenistan, Uzbekistan, Kazakhstan and Azerbaijan, was investigated, the most controversial signs were defined and the results were compared with KMU 2010. The study used comparative and descriptive methods. conclusions:

Having analyzed the experience of transcoding of post-socialist countries we can draw such

1) $\boldsymbol{\Gamma}$ and $\boldsymbol{r}$. In five out of seven countries, there are two variants for the Cyrillic letter - two of them use $\boldsymbol{h}$ as a modifier, two of which - Uzbekistan and Kazakhstan - have attracted diacritics - $\breve{g}$ and $\boldsymbol{g}$, one country took another sign $-\boldsymbol{q}$.

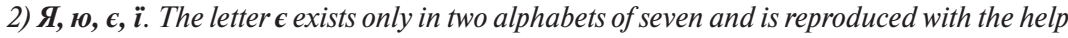
of the letter $\boldsymbol{e}$. The letter $\boldsymbol{e}$ (in this case the equivalent of the Ukrainian one) is reproduced as $\boldsymbol{e}$ in six of seven cases, only in Moldova there is an option ie. Letters $\boldsymbol{\omega}$ and $\boldsymbol{s}$ exist only in the Moldovan and Romanian Cyrillic alphabets and are translated as iu and ia accordingly. Letter $\ddot{i}$ wasn t in Cyrillic alphabets of the studied countries.

3) X in five of seven countries is transmitted as $\mathbf{j}$, in two of them - in Serbia and Turkmeni-

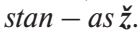

4) There is no unity observed about $\check{\boldsymbol{u}}$. This letter is transcoded as $\boldsymbol{I} \boldsymbol{i}, \boldsymbol{J} \boldsymbol{j}, \boldsymbol{Y} \mathbf{y}, \boldsymbol{Y} \boldsymbol{y}, \boldsymbol{I} \boldsymbol{t}$, in two cases - in Romania and Azerbaijan, it is not transmitted at all.

5) $\boldsymbol{b}$ in Turkmenistan is trancoded as $\boldsymbol{y}$, and in Moldova as $\boldsymbol{i}$. In other alphabets there is no such separate letter, but there are diacritics denoting softened consonants: (Uzbekistan and Kazakhstan), s-lj, $\boldsymbol{b}$-nj, $\boldsymbol{h}$-ć $\boldsymbol{i} \boldsymbol{u}$ - $\mathbf{d} \mathbf{z}$ (Serbia).

8) Such a sign as'(apostrophe) does not exist in any of the alphabets of the studied countries. If we consider the apostrophe for the equivalent of $\mathbf{z}$, then it also exists only in two countries - in Romania and in Uzbekistan - and is transmitted as $\breve{\boldsymbol{a}}$ and accordingly. So, the author got the rationale for the definition of $\boldsymbol{z} \boldsymbol{i} r, \boldsymbol{s}, \boldsymbol{\omega}, \boldsymbol{\epsilon}, \boldsymbol{i}, \boldsymbol{x}, \check{\boldsymbol{u}}, \boldsymbol{x}, \boldsymbol{u}, \boldsymbol{b}$, ' as the most controversial letters not only for the Ukrainian language but for all post-socialist countries as well. vowel.

Key words: Cyrillic, Latin, transcoding, transliteration, alphabet, graphic, consonant, 


\section{Ветуп}

Після підписання у 2016-2017 рр. Угоди про безвізовий режим України з СС й Угоди про асоціацію та про вільну торгівлю з СС відбувається переорієнтування великої частки українського бізнесу на ринки європейських країн. Тож виникає гостра потреба адекватного латинського транскодування українських власних назв - імен, прізвищ, найменувань компаній, топонімів, урбанонімів, національно-культурних процесів тощо. Ці й подібні процеси вмотивовують актуальність лінгвістичних досліджень у галузі транскодування різних мов.

У жовтні 2018 року МЗС України спільно із Центром стратегічних комунікацій StratCom Ukraine розпочало онлайн-кампанію \#CorrectUA, у рамках якої звертається до іноземних ЗМІ з метою коригування правопису міста Київ - \#KyivNotKiev. У рамках кампанії щоденно на сторінках МЗС України у Facebook та Twitter з'являються публікації, які містять випадки некоректного вживання назви Київ як Kiev провідними іноземними 3МI, такими як The New York Times, BBC, Reuters та інші. МЗС також запросило всіх небайдужих громадян України та її друзів долучитися до кампанії - використовуючи хештеги \#KyivNotKiev, \#CorrectUA й затегавши відповідні провідні іноземні ЗМІ у соцмедіа ${ }^{1}$.

Результатом ініціативи стала, наприклад, зміна написання назви столиці України медіа-групою The Guardian - відтепер це Kyiv. Відповідні зміни були внесені у стилістичний довідник видання. Журналіст видання Шон Вокер також зазначив можливість зміни й назви міста Одеса з Odessa на Odesa ${ }^{2}$, адже у першому випадку використовується мова-посередник, що суперечить принципам українсько-латинського транскодування.

Ця робота є частиною серії наших досліджень, присвячених розвитку української латинки у VII-XXI ст. і сучасним стандартам. Упродовж п'ятьох віків до аналізу історичного розвитку орфографії та фонетики, історії правопису були залучені М. Драгоманов, Б. Дідицький, П. Житецький, Й. Їречек, А. Кримський, Й. Лозинський, І. Огієнко, О. Потебня, І. Франко, О. Шахматов, М. Шашкевич - XIX ст.; О. Синявський, В. Сімович, М. Наконечний, Є. Тимченко - 20-30-і рр. ХХ ст.; Л. Булаховський, М. Жовтобрюх, Ю. Маслов, С. Пилипенко, А. Реформатський, Я. Рудницький, Ю. Шевельов, Л. Щерба, Р. Якобсон - 50-80-і рр. ХХ ст. Сьогодні це питання розробляють І. Кульчицький, Ю. Блонарович, А. Костенко, В. Костирко, М. Вакуленко, В. Грицеляк, О. Дуліченко, А. Д’яков, М. Лесюк, Н. Маліневська, В. Німчук, 3. Партико, П. Шекера. Незважаючи на таку потужну базу фундаментальних досліджень, тема відтворення літер української мови засобами латинської абетки досі є маловивченою.

У 2010 р. постановою Кабінету Міністрів України була затверджена офіційна паспортна транслітерація, але наразі в Україні різною мірою

${ }^{1}$ МЗС починає всесвітню кампанію: Kyiv Not Kiev / Європейська правда. URL: https://www.eurointegration.com.ua/news/2018/10/2/7087647.

2 Видання The Guardian писатиме у своїх текстах Куіv замість Kiev / Европейська правда. URL: https://www.eurointegration.com.ua/news/2019/02/13/7092786. 
використовуються понад 20 стандартів українсько-латинського транскодування. Така кількість варіантів призводить до постійних проблем, пов'язаних із помилками неоднозначності зворотного транскодування, а також до правових колізій міжнародного рівня.

Мета цієї роботи - дослідити досвід переходу з кириличного до латиничного письма постсоціалістичних країн, а саме Румунії, Молдови, Сербії, Туркменістану, Узбекистану, Казахстану та Азербайджану, визначити найбільш спірні літери як в рамках однієї мови, так і за всім масивом загалом, порівняти результати з офіційним стандартом українсько-латинської транслітерації КМУ 2010 та спробувати використати цей досвід для оновлення українського стандарту.

\section{Методи та методики дослідження}

У роботі було використано описовий і порівняльний методи для висвітлення умов, за яких відбувався перехід з кириличного алфавіту на латиничне письмо в зазначених країнах, і порівняння цих кирилично-латиничних відповідників між собою в синхронії та діахронії.

\section{Результати та дискусії}

Наразі у світі існують та більшою чи меншою мірою використовуються понад 20 офіційних стандартів українсько-латинського транскодування³. Частина з них (Науковий, ALA-LC, Британський, BGN/PCGN, ISO 9, Українська латинка, Французький, Німецький, Іспанський, Португальський) були створені іноземцями й затверджені урядами інших держав.

Друга частина була розроблена на території України та начебто українськими спеціалістами, але майже половина з цих систем були написані в той час, коли наша держава була частиною інших політичних утворень, i це не могло не позначитись на мові. Це такі системи й стандарти, як ГОСТ 1971, ГОСТ 1986, ТКПН 1994, Держстандарт 1995, УКППТ 1996, ГОСТ 7.792000 Б, Паспортний 2004, Паспортний 2007, система В. Грицеляка, Паспортний 2010, система A. Макухи (Ukrainian URL 2013). Офіційним в Україні наразі є КМУ 2010.

До цього списку можна додати системи окремих країн, наприклад Польщі, Нідерландів, Данії, Латвії, Естонії тощо, які відрізняються від перерахованих стандартів і використовують літери та їхні сполуки, властиві тільки національним мовам цих держав.

За світовими стандартами й угодами (зокрема резолюціями ООН: $\mathrm{iV} / 20$ - «Про зменшення кількості екзонімів» та V/13 - «Про переважність національних офіційних форм географічних назв») власні назви

${ }^{3}$ Тут і надалі ми використовуємо термін «транскодування» як спосіб перекладу, коли звукова та/або графічна форма слова вихідної мови передається засобами абетки мови перекладу. Транскодування включає такі поняття як 1) транскрибування, 2) транслітерування, 3) змішане транскодування, 4) адаптивне транскодування. Коли йдеться по стандарт КМУ 2010, ми користуємося поняттям «транслітерація», відповідно до назви Постанови Кабінету Міністрів України: https://www.kmu.gov.ua/ ua/npas/243262567. 
в середовищі іншої мови повинні зберігати автентичне написання: San-Jose (місто в США), Сојїо (провінція Канади) (Вакуленко, 2016). Якщо ж вихідна форма написана нелатинською абеткою, то іiї заведено транслітерувати латиницею цієї ж мови. Наприклад, у грецьких містах назви вулиць подаються елліницею та латиницею. Японська держава працює над створенням латиниці для своєї державної мови - системи ромадзі. Розробляючи систему піньїнь, розуміє важливість цього питання й Китайська народна республіка.

В Україні, де за 25 років періоду незалежності держава не спромоглася створити паралельну латинську абетку для української мови, маємо таку ситуацію, коли українське прізвище Ющенко у світі одночасно відтворюється такими способами, як Juschtschenko, Joesjtsjenko, Iouchtchenko, Juszczenko, Jusjtjenko, Juscsenko, Yushenko, Iúsxenko, Yúshchenko, Juštšenko, Iușcenko, Yuşçenko, Yuşşenko. Інший приклад - одне з найпоширеніших українських прізвищ Шевченко - «перекладається» як Ševčenko, Shewchenko, Chévtchénko, Schewtschenko, Chewtchenko, Szewczenko, Shevchenko. Назва українського міста Харкова дублюється як Kharkiw, Kharkiv, Charkiw, Jarkiw, Harkiv і навіть Kharkov. Надзвичайно яскраво ілюструє негативні наслідки відсутності єдиної системи українсько-латинської транслітерації історія запису імені Сергій в українських закордонних паспортах упродовж 1971-2019 рр.: Sergy, Sergiy, Serhiy, Sergii.

Що ж не так $з$ офіційною українсько-латинською транслітерацією КМУ 2010? Наші дослідження, а також роботи українського лінгвістичного кола згадують такі особливості таблиці, як основні недоліки офіційного стандарту:

- одна й та сама літера латинського алфавіту відповідає різним літерам українського, у деяких випадках потрібно тільки вгадувати (наприклад, латинська літера $\boldsymbol{i}$ може позначати одну з трьох українських літер $\check{\boldsymbol{u}}, \boldsymbol{i}$ або $\boldsymbol{i})$, що призводить до проблем під час зворотного транскодування,

- колонка «Позиція в слові», яка вимагає від користувачів стандарту українсько-латинського й латинсько-українського транскодування мати певний рівень філологічної підготовки, що суперечить принципу транслітерації, про який говорив ще О. Реформатський (Реформатский, 1960: 97); від позиції в слові залежать такі літери, як $\check{\boldsymbol{u}} \boldsymbol{\epsilon}, \boldsymbol{ю}, \boldsymbol{g}, \boldsymbol{i}$,

- ігнорування твердої та м'якої вимови, позначених апострофом і м'яким знаком відповідно, тож, наприклад, прізвища Гальченко і Галченко пишуться однаково - Halchenko, а назви міст Знамянка і Знам'янка - Znamianka, а це порушує принципи точності та взаємної однозначності,

- передача літери $\boldsymbol{u}$ через ts (залишок французької транслітераціі), що призводить до плутанини прізвищ, наприклад, Тоцька і Тотська - вони пишуться однаково як Totska,

- декілька варіантів для передачі літери $\boldsymbol{\imath}-\boldsymbol{h}, \boldsymbol{h} \boldsymbol{g}$ - залежно від позиції в слові.

Щоб зрозуміти, як ці та подібні виклики вирішували інші країни, ми дослідили досвід постсоціалістичних країн, які в різний час перейшли з кирилиці на латиницю. Умовно їх можна поділити на дві групи: європейські 
(Румунія, Молдова й Сербія) та азійські (Туркменістан, Узбекистан, Казахстан й Азербайджан). Дискусії щодо того, чи був достатньо обгрунтованим і необхідним цей крок, досі ведуться в Туркменістані й Узбекистані і певною мірою - у Молдові (у невизнаній республіці Придністров’я офіційною є кирилиця). Найкраще 3 операцією «латиниця» впоралися Румунія, Сербія, Казахстан й Азербайджан. Хоча, очевидно, зміни в мові майже завжди пов’язані зі змінами соціальними та політичними, у цій розвідці ми робили акцент саме на графічних трансформаціях, подаючи мінімальний історичний коментар до історії кожної з них.

Румунія. Старорумунська кирилиця використовувалася для запису волоської та молдавської мов у Валахії, Трансильванії та Молдавському князівстві. В об'єднаній Румунії з початку 1860-х рр. офіційно став використовуватися румунський алфавіт на латинській основі, у Бессарабії ж з XIX століття поширився російський алфавіт.

Між 1932 і 1938 рр. у Румунії офіційно використовувалася латиниця, але перехід румунської писемності на латиницю був двоступеневим: спочатку в 1830-1850-і pр. застосовувався так званий «перехідний алфавіт», що включав як кириличні, так і латинські знаки, і лише за кілька років була введена власне латиниця:

Таблиця 1

\section{Румунська кирилиця та латиниця (подано у хронології)}

\begin{tabular}{|c|c|c|c|}
\hline $\begin{array}{c}\text { Кирилиця } \\
\text { до 1830-1850-і pp. }\end{array}$ & $\begin{array}{c}\text { Перехідна латиниця } \\
\text { у 1830-1850-і pp. }\end{array}$ & $\begin{array}{c}\text { Остаточна } \\
\text { латиниця } 31860 \text { р. }\end{array}$ & Примітки \\
\hline a & $\mathrm{a}$ & $\mathrm{a}$ & \\
\hline 6 & 6 & $\mathrm{~b}$ & \\
\hline B & $\mathrm{B}$ & $\mathrm{V}$ & \\
\hline$\Gamma$ & $\mathrm{g}$ & g, gh & \\
\hline д & $\mathrm{d}$ & $\mathrm{d}$ & \\
\hline$\epsilon, \mathrm{e}$ & e & e & $\begin{array}{c}\boldsymbol{\epsilon} \text { на початку слова, } \\
\boldsymbol{e}-\text { в інших випадках }\end{array}$ \\
\hline ж & ж & $\mathrm{j}$ & \\
\hline 3 & $\mathrm{z}, \mathrm{d}$ & $\mathrm{Z}$ & \\
\hline i, и & $\mathrm{i}, \breve{1}, \mathrm{i}$ & $\mathrm{i}$ & $\begin{array}{r}\boldsymbol{i} \text { перед голосними, } \boldsymbol{u}- \\
\text { перед приголосними і } \\
\text { в кінці слова, часто ви- } \\
\text { користовувалася як } \boldsymbol{i} \\
\end{array}$ \\
\hline Й & - & - & \\
\hline $\mathrm{K}$ & $\mathrm{k}$ & $\mathrm{c}, \mathrm{ch}$ & \\
\hline л & 1 & 1 & \\
\hline $\mathrm{M}$ & $\mathrm{m}$ & $\mathrm{m}$ & \\
\hline $\mathrm{H}$ & $\mathrm{n}$ & $\mathrm{n}$ & \\
\hline $\mathrm{O}$ & $\mathrm{O}$ & o & \\
\hline$\Pi$ & $\mathrm{p}$ & $\mathrm{p}$ & \\
\hline $\mathrm{p}$ & $\mathrm{r}$ & $\mathrm{r}$ & \\
\hline
\end{tabular}




\begin{tabular}{|c|c|c|c|}
\hline $\begin{array}{c}\text { Кирилиця } \\
\text { до 1830-1850-і pp. } \\
\end{array}$ & $\begin{array}{c}\text { Перехідна латиниця } \\
\text { у 1830-1850-і рр. }\end{array}$ & \begin{tabular}{|c|} 
Остаточна \\
латиниця 31860 р. \\
\end{tabular} & Примітки \\
\hline $\mathrm{c}$ & $\mathrm{S}$ & $\mathrm{S}$ & \\
\hline $\mathrm{T}$ & $\mathrm{t}$ & $\mathrm{t}$ & \\
\hline $\mathrm{y}$ & $\gamma$ & $\mathrm{u}$ & \\
\hline oy & $\gamma$ & $\mathrm{u}$ & $\begin{array}{c}\text { на початку слова як по- } \\
\text { зиційний варіант } \boldsymbol{y}\end{array}$ \\
\hline$\phi$ & $\mathrm{f}$ & $\mathrm{f}$ & \\
\hline $\mathrm{x}$ & $\mathrm{x}$ & $\mathrm{h}$ & \\
\hline ц & ц & $\underline{t}$ & \\
\hline $\mathrm{Y}$ & $\mathrm{Y}$ & $\mathrm{c}$ & перед $\boldsymbol{i}$ та $\boldsymbol{e}$ \\
\hline ш & ш & ș & \\
\hline щ & щ & şt & \\
\hline $\mathrm{b}$ & $\mathrm{b}$ & $\breve{a}$ & \\
\hline Ы & - & - & $\begin{array}{c}\text { Літера ы зазвичай } \\
\text { включалася до складу } \\
\text { алфавіту, але фактично } \\
\text { на письмі не викорис- } \\
\text { товувалася. }\end{array}$ \\
\hline b & - & - & $\begin{array}{c}\text { У ряді текстів в вжива- } \\
\text { лася після приголосних } \\
\text { у кінці слів. }\end{array}$ \\
\hline$ю$ & iy, & $\mathrm{iu}$ & \\
\hline Я & ia & ia & \\
\hline
\end{tabular}

Молдова. Молдавський кириличний алфавіт був створений у 1920-і роки на основі російського алфавіту й використовувався спочатку в Молдавській АРСР - у 1926-1932 і 1938-1940 pp., а потім у Молдавській РСР - з 1940 р. У проміжок з 1932 до 1938 рр. молдавський народ СРСР користувався латинізованим алфавітом, аналогічним румунському.

Постановою Ради міністрів Молдавської РСР від 2 серпня 1957 р. 3 молдавського алфавіту були виключені літери щ і $\boldsymbol{z}$, а постановою від 17 травня 1967 р. була введена буква ж̌.

Цей алфавіт отримав офіційний статус і використовувався в Молдавській РСР до 31 серпня 1989 р., коли Верховна Рада Молдавської РСР прийняла закон «Про повернення молдавській мові латинської графіки».

Тож таблиця переходу від кирилиці до латиниці у Молдові має такий вигляд:

Таблиця 2

Молдовська кирилиця та латиниця

\begin{tabular}{|c|c|c|}
\hline $\begin{array}{c}\text { Кирилиця } \\
\text { 1920-1989 pp. }\end{array}$ & $\begin{array}{c}\text { Латиниця } \\
\text { 3 1989 p. }\end{array}$ & Примітки \\
\hline $\mathrm{a}$ & $\mathrm{a}$ & \\
\hline 6 & $\mathrm{~b}$ & \\
\hline
\end{tabular}




\begin{tabular}{|c|c|c|}
\hline $\begin{array}{c}\text { Кирилиця } \\
1920-1989 \text { рр. }\end{array}$ & $\begin{array}{c}\text { Латиниця } \\
\text { з } 1989 \text { р. } \\
\end{array}$ & Примітки \\
\hline B & $\mathrm{v}$ & \\
\hline$\Gamma$ & $\mathrm{g}, \mathrm{gh}$ & $\boldsymbol{g} \boldsymbol{h}$ перед $\boldsymbol{i}$ або $\boldsymbol{e}$, в інших випадках $\boldsymbol{g}$ \\
\hline д & $\mathrm{d}$ & \\
\hline e & $\mathrm{e}, \mathrm{ie}$ & $\begin{array}{c}\text { ie після голосної та найчастіше на початку слова, } \\
\text { в інших випадках } \boldsymbol{e}\end{array}$ \\
\hline ж & $\mathrm{j}$ & \\
\hline Ж & $\mathrm{g}$ & перед $\boldsymbol{i}$ та $\boldsymbol{e}$ \\
\hline 3 & $\mathrm{Z}$ & \\
\hline и & i, ii & 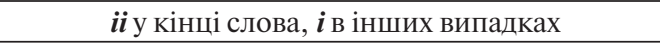 \\
\hline Й & $\mathrm{i}$ & перед голосними \\
\hline $\mathrm{K}$ & $\mathrm{c}, \mathrm{ch}$ & $\boldsymbol{c h}$ перед $\boldsymbol{i}$ та $\boldsymbol{e}$, в інших випадках - $\boldsymbol{c}$ \\
\hline л & 1 & \\
\hline $\mathrm{M}$ & $\mathrm{m}$ & \\
\hline $\mathrm{H}$ & $\mathrm{n}$ & \\
\hline $\mathrm{o}$ & $\mathrm{o}$ & \\
\hline$\Pi$ & $\mathrm{p}$ & \\
\hline $\mathrm{p}$ & $\mathrm{r}$ & \\
\hline $\mathrm{c}$ & $\mathrm{s}$ & \\
\hline $\mathrm{T}$ & $\mathrm{t}$ & \\
\hline $\mathrm{y}$ & $\mathrm{u}$ & \\
\hline$\phi$ & $\mathrm{f}$ & \\
\hline $\mathrm{x}$ & $\mathrm{h}$ & \\
\hline ц & $\underline{t}$ & \\
\hline ч & $\mathrm{c}$ & перед $\boldsymbol{i}$ та $\boldsymbol{e}$ \\
\hline Ш & Ș & \\
\hline Ы & $\hat{\mathrm{a}}, \hat{\mathrm{i}}$ & â в середині слова, î на початку і в кінці \\
\hline b & $\mathrm{i}$ & у кінці слова \\
\hline Э & $\breve{a}$ & \\
\hline Ю & iu & \\
\hline я & ea, ia & \\
\hline
\end{tabular}

Якщо проаналізувати цю таблицю й порівняти молдовську латиницю із сучасним офіційним українським стандартом транслітерації (КМУ 2010), то привертають увагу декілька моментів:

- існування двох варіантів транскодування для літери $\boldsymbol{z}-\boldsymbol{g}, \boldsymbol{g} \boldsymbol{h}$, в українському варіанті $\boldsymbol{g}$ і $\boldsymbol{h}$ (для $\boldsymbol{\boldsymbol { \tau }}$ і г відповідно);

- $\boldsymbol{ю}$ і $\boldsymbol{я}$ транслітеруються як $\boldsymbol{i u}$ і $\boldsymbol{i a}$ - як і в українському стандарті не на початку слова;

- $\epsilon$ декілька варіантів для літери $\boldsymbol{x}-\boldsymbol{j}$ (тверда) й жั $-\boldsymbol{g}$ (пом'якшена);

- $\boldsymbol{b}, \boldsymbol{u}, \boldsymbol{u}$ транскодуються за допомогою знака $\boldsymbol{i}$;

- $\boldsymbol{\kappa}$ передається за допомогою $\boldsymbol{i} \boldsymbol{c h}$; 
- літера $\boldsymbol{b}$ (український відповідник $\boldsymbol{u}$ ) передається двома способами $\hat{a}, \hat{\imath}$;

- для позначення $\boldsymbol{u}$ і $\boldsymbol{u}$ використовуються діакритики $-\boldsymbol{t} \mathrm{i}$ ș відповідно.

Як бачимо, молдовська латинка дуже схожа на румунську, окрім того, що тут літери й і $\boldsymbol{b}$ не передаються взагалі, а літера $\boldsymbol{щ}$ відтворюється як șt.

Сербія. Хоча кирилиця тут має багатовікову історію й почала використовуватись з XX століття (найдавніша пам'ятка «Напис царя Самуїла» відноситься до 996 року), остаточно адаптував і створив абетку за фонетичним принципом - вуковицю - у 1814 р. сербський мовознавець В. Караджич. Латинську ж версію - гаєвицю - за прикладом чеської мови уклав хорватський мовознавець Л. Гай 1830 р., вона є ідентичною хорватській і боснійській абеткам.

Цікавим є те, що сербська використовує паралельно кириличну та латинську абетки, носії мови читають обидва письма однаково добре. Хоча Рада стандартизації сербської мови понад півстоліття визнає офіційний статус обох алфавітів, у сучасній мові уряд офіційно використовує кирилицю, що закріплено Конституцією 2006 р. Але закон не регулює використання алфавітів у стандартизованій мові, тобто вибір абетки повністю залежить від особистих побажань мовця (це стосується, зокрема, книг, медіа, торгівлі тощо). Виняток становить паперова продукція уряду та письмова комунікація з державними службовцями, які слід проводити кирилицею. Щоправда, навіть в офіційних документах уряду цієї конституційної вимоги часто не дотримуються. Таким чином, обидві абетки фактично мають абсолютно рівні права:

Таблиця 3

Сербська кирилиця та латиниця (подано в хронології)

\begin{tabular}{|c|c|c|c|}
\hline $\begin{array}{c}\text { Сербська вуковиця } \\
\text { з } 1814 \text { p. } \\
\end{array}$ & $\begin{array}{c}\text { Сербська гаєвиця } \\
31830 \text { р. } \\
\end{array}$ & $\begin{array}{c}\text { Сербська вуковиця } \\
\text { з } 1814 \text { р. } \\
\end{array}$ & $\begin{array}{c}\text { Сербська гаєвиця } \\
\text { з } 1830 \text { р. } \\
\end{array}$ \\
\hline $\mathrm{a}$ & $\mathrm{a}$ & $\mathrm{H}$ & $\mathrm{n}$ \\
\hline 6 & $b$ & њ & $\mathrm{nj}$ \\
\hline B & $\mathrm{V}$ & o & o \\
\hline$\Gamma$ & $\mathrm{g}$ & п & $\mathrm{p}$ \\
\hline д & $\mathrm{d}$ & $\mathrm{p}$ & $\mathrm{r}$ \\
\hline 万 & d & $\mathrm{c}$ & $\mathrm{s}$ \\
\hline $\mathrm{e}$ & $\mathrm{e}$ & $\mathrm{T}$ & $\mathrm{t}$ \\
\hline ж & ž & $\hbar$ & ć \\
\hline 3 & $\mathrm{Z}$ & $\mathrm{y}$ & $\mathrm{u}$ \\
\hline и & $\mathrm{i}$ & $\phi$ & $\mathrm{f}$ \\
\hline $\mathrm{j}$ & $\mathrm{j}$ & $\mathrm{x}$ & $\mathrm{h}$ \\
\hline $\mathrm{K}$ & $\mathrm{k}$ & Ц & $\mathrm{c}$ \\
\hline л & 1 & $\mathrm{Y}$ & $\check{c}$ \\
\hline Љ & $\mathrm{lj}$ & $Џ$ & $\mathrm{dž}$ \\
\hline M & $\mathrm{m}$ & Ш & š \\
\hline
\end{tabular}


У контексті пошуку найкращої системи українсько-латинського транскодування в сербській гаєвиці особливо прикметним є існування літери $\boldsymbol{j}$ - замістила традиційне давньокириличне акцентоване $\boldsymbol{u}(\check{\boldsymbol{u}})$, iї використовував у своїй системі транслітерації і М. Драгоманов (Міньковська, 2018). Саме вона використовується для м'яких $\boldsymbol{s}, \boldsymbol{b}-\boldsymbol{l} \boldsymbol{j}$ i $\boldsymbol{n} \boldsymbol{j}$ відповідно. У той же час пом'якшені дж і $\boldsymbol{\imath}$ відтворюються за допомогою штриха й акута у $\boldsymbol{d}$ i $\boldsymbol{c}$ відповідно.

3 азійських країн з кирилиці на латиницю перейшли Туркменістан, Узбекистан, Казахстан й Азербайджан. Майже всі вони мали декілька періодів і, відповідно, декілька варіантів латиниці.

Туркменістан. Після розпаду СРСР на початку 1990-х pp. у Туркменістані розпочалася дискусія щодо переходу на латинську писемність. Група вчених Інституту мовознавства на чолі з М. Соєговим розробила перший варіант нового алфавіту, який був опублікований в газеті «Түркменістан» 19 серпня 1992 р. Особливістю цього проекту стало нетрадиційне використання знаків $\boldsymbol{q}, \boldsymbol{v}, \boldsymbol{x}-$ вони повинні були замінити кириличні літери $\boldsymbol{\theta}, \boldsymbol{Y}, \boldsymbol{u}$ відповідно. У тому ж році було запропоновано ще ряд проектів.

У січні 1993 р. в Академії наук Туркменістану було сформовано комісію з розробки алфавіту. Уже 12 квітня 1993 р. Меджліс затвердив президентський указ про новий алфавіт, особливістю якого стало використання для позначення деяких специфічних звуків туркменської мови знаків валют долара, ієни й фунта.

Незабаром замість цього алфавіту був уведений інший варіант, який використовується й зараз. 32000 р. цей алфавіт став єдиним у всіх офіційних сферах країни:

Таблиця 4

Туркменська кирилиця та латиниця (подано в хронології)

\begin{tabular}{|c|c|c|c|c|}
\hline $\begin{array}{c}\text { Латиниця } \\
\text { 1929-1940 pp. }\end{array}$ & $\begin{array}{c}\text { Кирилиця } \\
\text { 1940-1995 pр. }\end{array}$ & $\begin{array}{c}\text { Латиниця } \\
1992 \text { р. } \\
\end{array}$ & $\begin{array}{c}\text { Латиниця } \\
1993 \text { р. } \\
\end{array}$ & $\begin{array}{c}\text { Латиниця } \\
31995 \text { p. } \\
\end{array}$ \\
\hline $\mathrm{a}$ & $\mathrm{a}$ & $\mathrm{a}$ & $\mathrm{a}$ & $\mathrm{a}$ \\
\hline$b$ & 6 & $\mathrm{~b}$ & b & $b$ \\
\hline $\mathrm{V}$ & B & W & $\mathrm{W}$ & W \\
\hline ol & $\Gamma$ & $\mathrm{g}$ & $\mathrm{g}$ & $\mathrm{g}$ \\
\hline d & д & $\mathrm{d}$ & $\mathrm{d}$ & $\mathrm{d}$ \\
\hline e & $\ni, \mathrm{e}$ & ea & e & e \\
\hline$\partial$ & $\partial$ & ea & ea & ä \\
\hline$z$ & Ж & $\mathrm{jh}$ & $£ \Gamma$ & $\check{Z}$ \\
\hline ç & ж & $\mathrm{j}$ & $\mathrm{j}$ & $\mathrm{j}$ \\
\hline Z & 3 & Z & Z & $\mathrm{Z}$ \\
\hline $\mathrm{i}$ & и & $\mathrm{i}$ & $\mathrm{i}$ & $\mathrm{i}$ \\
\hline $\mathrm{j}$ & й & $\mathrm{y}$ & $¥ \ddot{y}$ & ý \\
\hline$q$ & $\mathrm{~K}$ & $\mathrm{k}$ & $\mathrm{k}$ & $\mathrm{k}$ \\
\hline 1 & л & 1 & 1 & 1 \\
\hline
\end{tabular}




\begin{tabular}{|c|c|c|c|c|}
\hline $\begin{array}{c}\text { Латиниця } \\
\text { 1929-1940 pp. }\end{array}$ & $\begin{array}{c}\text { Кирилиця } \\
\text { 1940-1995 рр. }\end{array}$ & $\begin{array}{c}\text { Латиниця } \\
1992 \text { р. } \\
\end{array}$ & $\begin{array}{c}\text { Латиниця } \\
1993 \text { р. }\end{array}$ & $\begin{array}{r}\text { Латиниця } \\
31995 \text { р. } \\
\end{array}$ \\
\hline $\mathrm{m}$ & $\mathrm{M}$ & $\mathrm{m}$ & $\mathrm{m}$ & $\mathrm{m}$ \\
\hline $\mathrm{n}$ & $\mathrm{H}$ & $\mathrm{n}$ & $\mathrm{n}$ & $\mathrm{n}$ \\
\hline , & $\mathrm{H}$ & ng & $\tilde{\mathrm{n}}$ & $\check{n}$ \\
\hline $\mathrm{O}$ & 0 & 0 & 0 & 0 \\
\hline$\theta$ & $\theta$ & $q$ & ö & $\ddot{o}$ \\
\hline $\mathrm{p}$ & $\Pi$ & $\mathrm{p}$ & $\mathrm{p}$ & $\mathrm{p}$ \\
\hline $\mathrm{r}$ & $\mathrm{p}$ & $\mathrm{r}$ & $\mathrm{r}$ & $r$ \\
\hline $\mathrm{s}$ & $\mathrm{c}$ & $\mathrm{s}$ & $\mathrm{s}$ & $\mathrm{s}$ \\
\hline $\mathrm{t}$ & $\mathrm{T}$ & $\mathrm{t}$ & $\mathrm{t}$ & $\mathrm{t}$ \\
\hline $\mathrm{u}$ & $\mathrm{y}$ & $\mathrm{u}$ & $\mathrm{u}$ & $\mathrm{u}$ \\
\hline $\mathrm{y}$ & $\mathrm{Y}$ & $\mathrm{V}$ & $\ddot{u}$ & $\ddot{u}$ \\
\hline $\mathrm{f}$ & $\phi$ & $\mathrm{f}$ & $\mathrm{f}$ & $\mathrm{f}$ \\
\hline $\mathrm{h}$ & $\mathrm{X}$ & $\mathrm{h}$ & $\mathrm{h}$ & $\mathrm{h}$ \\
\hline ts & Ц & ts & - & - \\
\hline $\mathrm{c}$ & $\mathrm{\Psi}$ & $\mathrm{c}$ & ç & ç \\
\hline Ş & ш & sh & $\$ \varnothing$ & Ş \\
\hline- & щ & - & - & - \\
\hline- & $\mathrm{b}$ & - & - & - \\
\hline $\mathrm{b}$ & Ы & $x$ & $\mathrm{y}$ & $\mathrm{y}$ \\
\hline- & $\mathrm{b}$ & - & - & - \\
\hline$\breve{\mathrm{a}}$ & Э & $\breve{a}$ & - & - \\
\hline iy, ì & Ю & iu & - & - \\
\hline ia & Я & ia & - & - \\
\hline
\end{tabular}

Якщо проаналізувати три варіанти туркменської латиниці й порівняти остаточну версію з офіційним українсько-латинським стандартом, то цікавими $€$ такі рішення:

- $\boldsymbol{в}$ усе-таки відтворюється за допомогою $\boldsymbol{w}$, а не $\boldsymbol{v}$ (як у КМУ 2010);

- 2 вирішили записувати як $\boldsymbol{g}$;

- $\boldsymbol{e}$ (українське $\boldsymbol{\epsilon}$ ) транскодують за допомогою $\boldsymbol{e}$, а знак $\boldsymbol{\boldsymbol { s }}$ (українське $\boldsymbol{e}$ ) - за допомогою $\ddot{a}$;

- знак й вирішили передавати не $\boldsymbol{j}$ (як у першому варіанті латиниці), а $\boldsymbol{y}$;

- $\boldsymbol{u}$ передає знак $\boldsymbol{x}$, а $\boldsymbol{\varphi}$ і $\boldsymbol{u}-\boldsymbol{c}$ і іs, тобто діакритика, відповідно;

- звук $\boldsymbol{b}$ (український знак $\boldsymbol{u}$ ) записується за допомогою $\boldsymbol{y}$ - як і в українському стандарті;

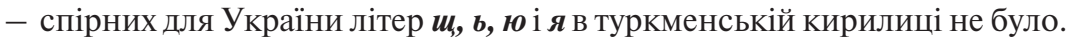

Узбекистан. 2 вересня 1993 р. у Республіці Узбекистан вступив у силу закон «Про введення узбецького алфавіту, заснованого на латинській графіці». 3 урахуванням побажань широкої громадськості цей закон було спрямовано на «створення сприятливих умов, що прискорюють усебічний прогрес республіки й уходження іiї в систему світової комунікації», а відповідна постанова Верховної ради зазначила: «Перехід на новий алфавіт здійснювати 
поетапно, з повним завершенням цієї роботи на 1 вересня 2010 року» (Палата Олий Мажлиса Республики Узбекистан, 1993).

Зрозуміло, що така масштабна зміна викликала значні трансформації в роботі всіх державних і приватних інституцій країни, особливо сфери освіти, науки, культури, друку й інформаційної політики, але торкнулася абсолютно кожного громадянина, оскільки на всіх підприємствах мали бути створені спеціальні робочі групи з організації навчання співробітників і співробітниць новому алфавіту із забезпеченням необхідними для цього підручниками, навчальними посібниками й технічними засобами. Такі групи в державних інституціях фінансувалися із державного бюджету, а приватні компанії мали знайти кошти для цього самостійно.

Полеміка щодо переходу Узбекистану на латиницю точиться й до сьогодні, і основна їі причина - надто сповільнене виконання наказу й існування в країні фактично двох алфавітів одночасно. Робоча група з удосконалення узбецького алфавіту, заснованого на латиниці, при Ташкентському державному університеті узбецької мови й літератури в листопаді 2018 р. опублікувала проект оновленого узбецького алфавіту, обговорення якого велося протягом 2016-2018 рр.:

Таблиця 5

Узбецька кирилиця та латиниця (подано в хронології)

\begin{tabular}{|c|c|c|c|}
\hline $\begin{array}{c}\text { Латиниця } \\
\text { 1934-1940 pp. }\end{array}$ & $\begin{array}{l}\text { Кирилиця } \\
31940 \text { рр. } \\
\end{array}$ & $\begin{array}{c}\text { Латиниця } \\
\text { 1995-2018 pp. }\end{array}$ & $\begin{array}{c}\text { Латиниця } \\
32018 \text { p. }\end{array}$ \\
\hline $\mathrm{a}$, ə & $\mathrm{a}$ & $\mathrm{a}$ & $\mathrm{a}$ \\
\hline $\mathrm{b}$ & 6 & $\mathrm{~b}$ & $\mathrm{~b}$ \\
\hline $\mathrm{d}$ & д & $\mathrm{d}$ & $\mathrm{d}$ \\
\hline $\mathrm{e}$ & e,э & $\mathrm{e}$ & $\mathrm{e}$ \\
\hline $\mathrm{f}$ & $\phi$ & $\mathrm{f}$ & $\mathrm{f}$ \\
\hline $\mathrm{g}$ & $\Gamma$ & $g^{6}$ & $\mathrm{~g}$ \\
\hline o & $\mp$ & $\mathrm{g}$ & $\breve{\mathrm{g}}$ \\
\hline $\mathrm{h}$ & $x$ & $\mathrm{~h}$ & $\mathrm{~h}$ \\
\hline $\mathrm{i}$ & и & $\mathrm{i}$ & $\mathrm{i}$ \\
\hline ç, z & ж & $\mathrm{j}$ & $\mathrm{j}$ \\
\hline $\mathrm{k}$ & $\mathrm{K}$ & $\mathrm{k}$ & $\mathrm{k}$ \\
\hline 1 & л & 1 & 1 \\
\hline $\mathrm{m}$ & M & $\mathrm{m}$ & $\mathrm{m}$ \\
\hline $\mathrm{n}$ & $\mathrm{H}$ & $\mathrm{n}$ & $\mathrm{n}$ \\
\hline $\mathrm{a}, \mathrm{o}$ & $\mathrm{O}$ & $\mathrm{O}$ & $\mathrm{O}$ \\
\hline $\mathrm{p}$ & $\Pi$ & $\mathrm{p}$ & $\mathrm{p}$ \\
\hline$q$ & қ & $\mathrm{q}$ & $\mathrm{q}$ \\
\hline $\mathrm{r}$ & $\mathrm{p}$ & $\mathrm{r}$ & $\mathrm{r}$ \\
\hline $\mathrm{s}$ & $\mathrm{c}$ & $\mathrm{s}$ & $\mathrm{s}$ \\
\hline$t$ & $\mathrm{~T}$ & $t$ & $t$ \\
\hline
\end{tabular}




\begin{tabular}{|c|c|c|c|}
\hline $\mathrm{u}$ & $\mathrm{y}$ & $\mathrm{u}$ & $\mathrm{u}$ \\
\hline $\mathrm{v}$ & $\mathrm{B}$ & $\mathrm{v}$ & $\mathrm{v}$ \\
\hline $\mathrm{x}$ & $\mathrm{x}$ & $\mathrm{x}$ & $\mathrm{x}$ \\
\hline $\mathrm{j}$ & $\breve{\mathrm{H}}$ & $\mathrm{y}$ & $\mathrm{y}$ \\
\hline $\mathrm{Z}$ & 3 & $\mathrm{Z}$ & $\mathrm{Z}$ \\
\hline $\mathrm{o}$ & $\breve{y}$ & $\mathrm{O}^{6}$ & $\mathrm{o}$ \\
\hline $\mathrm{s}$ & Ш & $\mathrm{sh}$ & $\mathrm{s}$ \\
\hline $\mathrm{c}$ & $\mathrm{u}$ & $\mathrm{ch}$ & $\mathrm{c}$ \\
\hline $\mathrm{n}$ & $\mathrm{H \Gamma}$ & $\mathrm{ng}$ & $\mathrm{ng}$ \\
\hline, & $\mathrm{b}$ &, &, \\
\hline
\end{tabular}

Основні зміни - відмова від буквених поєднань $\boldsymbol{s} \boldsymbol{h}$ і $\boldsymbol{c h}$ на позначення кириличних $\boldsymbol{m}$ і $\boldsymbol{u}$, а також використання перевернутого апострофа в буквах $\boldsymbol{o}^{\boldsymbol{*}} \mathrm{i} \boldsymbol{g}$ “ для позначення специфічних $\check{\boldsymbol{y}} \mathrm{i} \boldsymbol{z}$. Після обговорень прийнято рішення не повертати знак $\overline{\boldsymbol{n}}$, що позначає звук нг, залишивши в алфавіті поєднання ng. Кириличні літери ю і $\boldsymbol{g}$ позначаються $\boldsymbol{y} \boldsymbol{u}$ і $\boldsymbol{y a}$. Кирилична $\boldsymbol{u}$ передається

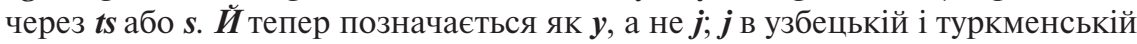
латиничних абетках позначає кириличний звук $\boldsymbol{x}$.

Казахстан. 31917 р. у Казахстані почала набирати популярність ідея латинізації. Арабське письмо протягом багатьох віків відігравало важливу роль не тільки для культури й освіти казахського населення, а й для підтримки духовних й історичних зв'язків з іншими східними країнами. Але на початку 20 століття ця графіка стала здаватися казахському суспільству перешкодою для історичного прогресу й народної самоідентифікації. Рух за перехід на латинську графіку особливо активізувався в 1923 р. Після ретельного обговорення в 1929 р. казахська мова перейшла на латиницю. Але життя латинського письма в Казахстані того разу було коротким: воно проіснувало з 1929 до 1939 рр.

Після здобуття незалежності постсоціалістичні країни знову замислилися про зміну графіки. У 2012 р. Президент Казахстану Н. Назарбаєв дав доручення до 2025 р. перевести державну мову на латинську графіку. Згідно 3 ним єдиний стандартний варіант казахського алфавіту в новій графіці повинен бути затверджений у 2017 р. Як ми бачимо, це завдання було виконане. 26 жовтня Указом Президента РК був затверджений проект казахського алфавіту на латинській графіці. Перехід планують завершити до 2025 р.:

Таблиця 6

Казахська кирилиця та латиниця (подано в хронології)

\begin{tabular}{|c|c|c|}
\hline $\begin{array}{c}\text { Латиниця } \\
\text { 1929-1939 pp. }\end{array}$ & $\begin{array}{c}\text { Кирилиця } \\
\mathbf{1 9 3 9 - 2 0 1 2} \mathbf{p p .}\end{array}$ & $\begin{array}{c}\text { Латиниця } \\
\mathbf{3 2 0 1 2} \mathbf{~ p .}\end{array}$ \\
\hline $\mathrm{a}$ & $\mathrm{a}$ & $\mathrm{a}$ \\
\hline $\mathrm{a}$ & э & $\mathrm{a}$ \\
\hline $\mathrm{b}$ & 6 & $\mathrm{~b}$ \\
\hline $\mathrm{d}$ & д & $\mathrm{d}$ \\
\hline
\end{tabular}




\begin{tabular}{|c|c|c|}
\hline $\begin{array}{l}\text { Латиниця } \\
\text { 1929-1939 pр. }\end{array}$ & $\begin{array}{c}\text { Кирилиця } \\
\text { 1939-2012 рр. }\end{array}$ & $\begin{array}{l}\text { Латиниця } \\
32012 \text { р. }\end{array}$ \\
\hline $\mathrm{e}$ & $\mathrm{e}$ & $\mathrm{e}$ \\
\hline $\mathrm{f}$ & $\phi$ & $\phi$ \\
\hline $\mathrm{g}$ & $\Gamma$ & $\mathrm{g}$ \\
\hline $\mathrm{g}^{\prime}$ & $F$ & $\mathrm{~g}^{\prime}$ \\
\hline $\mathrm{h}$ & $\mathrm{x}$ & $\mathrm{h}$ \\
\hline $\mathrm{i}$ & $\mathrm{i}$ & I i \\
\hline i' & И, й & $\mathrm{I}_{1}$ \\
\hline $\mathrm{j}$ & Ж & $\mathrm{j}$ \\
\hline $\mathrm{k}$ & $\mathrm{K}$ & $\mathrm{k}$ \\
\hline 1 & Л & 1 \\
\hline $\mathrm{m}$ & $\mathrm{M}$ & $\mathrm{m}$ \\
\hline $\mathrm{n}$ & $\mathrm{H}$ & $\mathrm{n}$ \\
\hline $\mathrm{n}^{\prime}$ & $\mathrm{H \Gamma}$ & ń \\
\hline 0 & 0 & 0 \\
\hline $\mathrm{o}^{\prime}$ & $\theta$ & ó \\
\hline $\mathrm{p}$ & $\Pi$ & $\mathrm{p}$ \\
\hline $\mathrm{q}$ & қ & $q$ \\
\hline $\mathrm{r}$ & $\mathrm{p}$ & $r$ \\
\hline $\mathrm{s}$ & $\mathrm{c}$ & $\mathrm{s}$ \\
\hline$s^{\prime}$ & Ш & $\begin{array}{c}\text { sh (офіційно подається } \\
\text { у кінці алфавіту) }\end{array}$ \\
\hline$c^{\prime}$ & ч & $\begin{array}{c}\text { ch (офіційно подається } \\
\text { у кінці алфавіту) }\end{array}$ \\
\hline $\mathrm{t}$ & $\mathrm{T}$ & $\mathrm{t}$ \\
\hline $\mathrm{u}$ & $¥$ & $\mathrm{u}$ \\
\hline и' & $\gamma$ & ú \\
\hline $\mathrm{V}$ & B & $\mathrm{v}$ \\
\hline $\mathrm{y}$ & Ы & $\mathrm{y}$ \\
\hline$y^{\prime}$ & $\mathrm{y}$ & ý \\
\hline $\mathrm{Z}$ & 3 & $\mathrm{Z}$ \\
\hline
\end{tabular}

Цікаво, що на питання, чому з алфавіту прибрали літеру и, директор Інституту мовознавства ім. А. Байтурсінова Ерден Кажибек відповів: «Літера Ц існує тільки в російській мові. Т+C виходить Ц». Також апостроф було замінено акутом. «Знак апострофа, який, по суті, є другим знаком, уводиться в структуру самої літери», - також прокоментував Е. Кажибек (Tengri News, 2018).

У казахській латинці літера г (українська $\boldsymbol{r}$ ) передається як $\boldsymbol{g}$, а z (ближчий до українського г) - як $\boldsymbol{g}$. Голосний $\boldsymbol{u}$ і приголосний $\boldsymbol{\boldsymbol { u }}$ передаються як $\boldsymbol{I}$ (у верхньому регістрі) та $\boldsymbol{\imath}$ (у нижньому). У транскодуванні $\boldsymbol{u}$ і $\boldsymbol{\iota}$ казахські, як й українські, учені вирішили відмовитися від діакритики й використовують sh і $\boldsymbol{c h}$ відповідно. 
Азербайджан. Країною, яка, мабуть, найкраще й найшвидше впоралась із операцією «латиниця», є Азербайджан. Перші проекти відтворення азербайджанської писемності за допомогою латинського алфавіту з'явилися ще в середині XIX ст., а після проголошення Азербайджанської РСР питання про латинізацію азербайджанської писемності знову актуалізувалося. У 1922 р. новий алфавіт було затверджено, а з 1925 р. він офіційно використовувався разом із арабським. 3 травня 1939 р. почали обговорювати перехід азербайджанського алфавіту на кирилицю - і в листопаді новий кириличний алфавіт, розроблений алфавітною комісією при Раді народних комісарів Азербайджанської РСР, був офіційно затверджений.

За радянських часів кириличний алфавіт в Азербайджані зазнав ряду змін, наприклад, з нього були вилучені літери $\boldsymbol{u}, \boldsymbol{e}, \boldsymbol{o}, \boldsymbol{s}$, а буква $\check{\boldsymbol{u}}$ була замінена на $\boldsymbol{j}$ з більш м'яким звучанням.

Пробудження на хвилі визвольного руху в Азербайджані національної самосвідомості спричинилося до ініціювання представниками інтелігенції заміни кириличної писемності на латиницю й законодавчого утвердження азербайджанської мови як державної. 1 серпня 2001 року згідно з наказом Президента країна за декілька місяців повністю перейшла на латиницю:

Таблиця 7

Азербайджанська кирилиця та латиниця (подано в хронології)

\begin{tabular}{|c|c|c|c|}
\hline $\begin{array}{c}\text { Латиниця } \\
\text { 1922-1933 pр. }\end{array}$ & $\begin{array}{c}\text { Латиниця } \\
\text { 1933-1939 рр. }\end{array}$ & $\begin{array}{c}\text { Кирилиця } \\
\text { 1939-1992 рр. }\end{array}$ & $\begin{array}{c}\text { Латиниця } \\
\text { з } 1992 \text { р. }\end{array}$ \\
\hline $\mathrm{a}$ & $\mathrm{a}$ & $\mathrm{a}$ & $\mathrm{a}$ \\
\hline $\mathrm{b}$ & B & 6 & $\mathrm{~b}$ \\
\hline $\mathrm{c}$ & ç & 4 & $\mathrm{c}$ \\
\hline ç & $\mathrm{c}$ & Ч & ç \\
\hline $\mathrm{d}$ & $\mathrm{d}$ & д & $\mathrm{d}$ \\
\hline $\mathrm{e}$ & $\mathrm{e}$ & $\mathrm{e}$ & $\mathrm{e}$ \\
\hline$\partial$ & $\partial$ & $\partial$ & $\partial$ \\
\hline $\mathrm{f}$ & $\mathrm{f}$ & $\phi$ & $\mathrm{f}$ \\
\hline o & $\mathrm{g}$ & К & $\mathrm{g}$ \\
\hline $\mathrm{g}$ & ol & $F$ & $\breve{\mathrm{g}}$ \\
\hline $\mathrm{h}$ & $\mathrm{h}$ & $\mathrm{h}$ & $\mathrm{h}$ \\
\hline $\mathrm{x}$ & $\mathrm{x}$ & $\mathrm{x}$ & $\mathrm{X}$ \\
\hline 1, & $b$ & Ы & 1 \\
\hline $\mathrm{i}$ & $\mathrm{i}$ & и & $\mathrm{i}$ \\
\hline$z$ & $z$ & ж & $\mathrm{j}$ \\
\hline $\mathrm{q}$ & $\mathrm{k}$ & $\mathrm{K}$ & $\mathrm{k}$ \\
\hline $\mathrm{k}$ & $\mathrm{q}$ & $\Gamma$ & $\mathrm{q}$ \\
\hline 1 & 1 & л & 1 \\
\hline $\mathrm{m}$ & $\mathrm{m}$ & $\mathrm{M}$ & $\mathrm{m}$ \\
\hline $\mathrm{n}$ & $\mathrm{n}$ & $\mathrm{H}$ & $\mathrm{n}$ \\
\hline $\mathrm{n}_{\mathrm{s}}$ & $\mathrm{n}$, & - & - \\
\hline
\end{tabular}




\begin{tabular}{|c|c|c|c|}
\hline $\begin{array}{c}\text { Латиниця } \\
\text { 1922-1933 pp. }\end{array}$ & $\begin{array}{c}\text { Латиниця } \\
\text { 1933-1939 pp. }\end{array}$ & $\begin{array}{c}\text { Кирилиця } \\
\text { 1939-1992 pp. }\end{array}$ & $\begin{array}{c}\text { Латиниця } \\
\text { 3 1992 p. }\end{array}$ \\
\hline $\mathrm{o}$ & $\mathrm{o}$ & $\mathrm{o}$ & $\mathrm{o}$ \\
\hline$\theta$ & $\mathrm{\theta}$ & $\Theta$ & $\mathrm{o}$ \\
\hline $\mathrm{p}$ & $\mathrm{p}$ & $\mathrm{\Pi}$ & $\mathrm{p}$ \\
\hline $\mathrm{r}$ & $\mathrm{r}$ & $\mathrm{p}$ & $\mathrm{r}$ \\
\hline $\mathrm{s}$ & $\mathrm{s}$ & $\mathrm{c}$ & $\mathrm{s}$ \\
\hline 3 & $\mathrm{~s}$ & Ш & $\mathrm{s}$ \\
\hline $\mathrm{t}$ & $\mathrm{t}$ & $\mathrm{T}$ & $\mathrm{t}$ \\
\hline $\mathrm{y}$ & $\mathrm{u}$ & $\mathrm{y}$ & $\mathrm{u}$ \\
\hline $\mathrm{u}$ & $\mathrm{y}$ & $\mathrm{Y}$ & $\ddot{\mathrm{u}}$ \\
\hline $\mathrm{v}$ & $\mathrm{v}$ & $\mathrm{B}$ & $\mathrm{v}$ \\
\hline $\mathrm{j}$ & $\mathrm{j}$ & $\mathrm{j}$ & $\mathrm{y}$ \\
\hline $\mathrm{z}$ & $\mathrm{z}$ & 3 & $\mathrm{z}$ \\
\hline
\end{tabular}

В азербайджанській латинці є аж три відповідники для варіантів літери $\boldsymbol{z}-\boldsymbol{g}, \breve{g}$ і $\boldsymbol{q}$. $\boldsymbol{~ I ~ п е р е д а є т ь с я ~ з а ~ д о п о м о г о ю ~} \boldsymbol{\imath}$, а $\boldsymbol{u}-$ за допомогою $\boldsymbol{i}$. $\boldsymbol{W}$ знову ж таки відтворюється за допомогою діакритика.

Аналіз варіантів української латинки, створеної українськими мовознавцями в XIX-XX ст. (Й. Лозинським, М. Драгомановим, В. Сімовичем, С. Пилипенком, Г. Шкурупієм і футуристичною школою, Я. Рудницьким, а також чехом Й. Їречком), проведений нами в роботі «Букви і політика: українські латиниці у IX-XX століттях» (Міньковська, 2018), дозволив довести, що кожна літера в цих системах залежала від того, ким, де, коли і для чого вони розроблялися. Вражає те, що лише 150 років тому в українських прогресивних колах серйозно обговорювалося питання щодо переходу української мови на латиницю. Усього лише за століття мовознавці змогли дійти згоди щодо передачі великої кількості літер. Спірними досі залишаються $\boldsymbol{\epsilon}$,

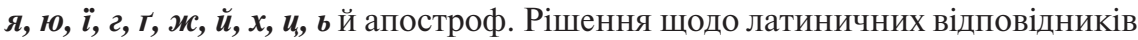
для цих кириличних літер у семи досліджуваних країнах нас цікавлять найбільше:

Таблиця 8

Порівняльна таблиця кириличних і фінальних латиничних абеток досліджуваних країн

\begin{tabular}{|c|c|c|c|c|c|c|c|}
\hline \multirow{2}{*}{$\begin{array}{c}\text { Кирилиця } \\
\text { досліджува- } \\
\text { них країн }\end{array}$} & \multicolumn{7}{|c|}{ Латиниця } \\
\hline & Румунія & Молдова & Сербія & Туркменістан & Узбекистан & Казахстан & Азербайджан \\
\hline $\mathrm{a}$ & $\mathrm{a}$ & $\mathrm{a}$ & $\mathrm{a}$ & $\mathrm{a}$ & $\mathrm{a}$ & $\mathrm{a}$ & $\mathrm{a}$ \\
\hline 6 & b & b & $b$ & b & b & b & $\mathrm{b}$ \\
\hline B & $\mathrm{V}$ & $\mathrm{V}$ & $\mathrm{V}$ & w & $\mathrm{V}$ & $\mathrm{V}$ & $\mathrm{V}$ \\
\hline$\Gamma$ & g, gh & g, gh & g & g & g & g & $q$ \\
\hline$\mp$ & - & - & - & - & $\breve{\mathrm{g}}$ & ǵ & $\breve{\mathrm{g}}$ \\
\hline K & - & - & - & - & - & - & $\mathrm{g}$ \\
\hline
\end{tabular}


ЛІНГВІСТИЧНІ ДОСЛІДЖЕННЯ: Зб. наук. праць ХНПУ ім. Г.С. Сковороди. - 2019. - Вип. 50

\begin{tabular}{|c|c|c|c|c|c|c|c|}
\hline \multirow{2}{*}{$\begin{array}{c}\text { Кирилиця } \\
\text { досліджува- } \\
\text { них країн }\end{array}$} & \multicolumn{7}{|c|}{ Латиниця } \\
\hline & Румунія & Молдова & Сербія & Туркменістан & Узбекистан & Казахстан & Азербайджан \\
\hline $\mathrm{h}$ & - & - & - & - & - & - & $\mathrm{h}$ \\
\hline д & $\mathrm{d}$ & $\mathrm{d}$ & $\mathrm{d}$ & $\mathrm{d}$ & $\mathrm{d}$ & $\mathrm{d}$ & $\mathrm{d}$ \\
\hline$\hbar$ & - & - & d & - & - & - & - \\
\hline $\mathrm{e}$ & $\mathrm{e}$ & $\mathrm{e}, \mathrm{ie}$ & $\mathrm{e}$ & $\mathrm{e}$ & $\mathrm{e}$ & $\mathrm{e}$ & $\mathrm{e}$ \\
\hline$\epsilon$ & $\mathrm{e}$ & - & - & $\mathrm{e}$ & - & - & - \\
\hline$\partial$ & - & - & - & ä & - & - & $\partial$ \\
\hline ж & $\mathrm{j}$ & $\mathrm{j}$ & $\check{Z}$ & $\check{z}$ & $\mathrm{j}$ & $\mathrm{j}$ & $\mathrm{j}$ \\
\hline Ӂ & - & $\mathrm{g}$ & - & - & - & - & - \\
\hline ж & - & - & - & $\mathrm{j}$ & - & - & - \\
\hline 3 & $\mathrm{z}$ & $\mathrm{z}$ & $\mathrm{z}$ & $\mathrm{z}$ & $\mathrm{z}$ & $\mathrm{z}$ & $\mathrm{z}$ \\
\hline и & $\mathrm{i}$ & $\mathrm{i}, \mathrm{ii}$ & $\mathrm{i}$ & $\mathrm{i}$ & $\mathrm{i}$ & - & $\mathrm{i}$ \\
\hline $\mathrm{i}$ & $\mathrm{i}$ & - & - & - & - & I i & - \\
\hline Й & - & $\mathrm{i}$ & $\mathrm{j}$ & ý & $\mathrm{y}$ & $\mathrm{I}_{1}$ & - \\
\hline j & - & - & - & - & - & - & $\mathrm{y}$ \\
\hline $\mathrm{K}$ & $\mathrm{c}, \mathrm{ch}$ & $\mathrm{c}, \mathrm{ch}$ & $\mathrm{k}$ & $\mathrm{k}$ & $\mathrm{k}$ & $\mathrm{k}$ & $\mathrm{k}$ \\
\hline қ & - & - & - & - & $q$ & $q$ & - \\
\hline л & 1 & 1 & 1 & 1 & 1 & 1 & 1 \\
\hline љ & - & - & $\mathrm{lj}$ & - & - & - & - \\
\hline $\mathrm{M}$ & $\mathrm{m}$ & $\mathrm{m}$ & $\mathrm{m}$ & $\mathrm{m}$ & $\mathrm{m}$ & $\mathrm{m}$ & $\mathrm{m}$ \\
\hline $\mathrm{H}$ & $\mathrm{n}$ & $\mathrm{n}$ & $\mathrm{n}$ & $\mathrm{n}$ & $\mathrm{n}$ & $\mathrm{n}$ & $\mathrm{n}$ \\
\hline њ & - & - & $\mathrm{nj}$ & - & - & - & - \\
\hline Н & - & - & - & $\check{n}$ & - & - & - \\
\hline НГ & - & - & - & - & ng & ń & - \\
\hline \multirow[t]{2}{*}{$\mathrm{o}$} & o & $\mathrm{o}$ & 0 & $\mathrm{o}$ & 0 & o & $\mathrm{o}$ \\
\hline & - & - & - & ö & - & ó & ö \\
\hline п & $\mathrm{p}$ & $\mathrm{p}$ & $\mathrm{p}$ & $\mathrm{p}$ & $\mathrm{p}$ & $\mathrm{p}$ & $\mathrm{p}$ \\
\hline $\mathrm{p}$ & $\mathrm{r}$ & $\mathrm{r}$ & $\mathrm{r}$ & $\mathrm{r}$ & $\mathrm{r}$ & $\mathrm{r}$ & $\mathrm{r}$ \\
\hline $\mathrm{c}$ & $\mathrm{s}$ & $\mathrm{s}$ & $\mathrm{s}$ & $\mathrm{s}$ & $\mathrm{s}$ & $\mathrm{s}$ & $\mathrm{s}$ \\
\hline $\mathrm{T}$ & $\mathrm{t}$ & $\mathrm{t}$ & $\mathrm{t}$ & $\mathrm{t}$ & $\mathrm{t}$ & $\mathrm{t}$ & $\mathrm{t}$ \\
\hline$\hbar$ & - & - & ć & - & - & - & - \\
\hline $\mathrm{y}$ & $\mathrm{u}$ & $\mathrm{u}$ & $\mathrm{u}$ & $\mathrm{u}$ & $\mathrm{u}$ & ý & $\mathrm{u}$ \\
\hline oy & $\mathrm{u}$ & - & - & - & - & - & - \\
\hline $\mathrm{Y}$ & - & - & - & $\ddot{\mathrm{u}}$ & - & ú & $\ddot{\mathrm{u}}$ \\
\hline y & - & - & - & - & ŏ & - & - \\
\hline$¥$ & - & - & - & - & - & $\mathrm{u}$ & - \\
\hline$\phi$ & $\mathrm{f}$ & $\mathrm{f}$ & $\mathrm{f}$ & $\mathrm{f}$ & $\mathrm{f}$ & - & $\mathrm{f}$ \\
\hline $\mathrm{X}$ & $\mathrm{h}$ & $\mathrm{h}$ & $\mathrm{h}$ & $\mathrm{h}$ & $\mathrm{x}$ & $\mathrm{h}$ & $\mathrm{x}$ \\
\hline
\end{tabular}


Міньковська І. І. Пряме кирилично-латиничне транскодування: досвід постсоціалістичних країн

\begin{tabular}{|c|c|c|c|c|c|c|c|}
\hline \multirow{2}{*}{$\begin{array}{c}\text { Кирилиця } \\
\text { досліджува- } \\
\text { них країн }\end{array}$} & \multicolumn{7}{|c|}{ Латиниця } \\
\hline & Румунія & Молдова & Сербія & Туркменістан & Узбекистан & Казахстан & Азербайджан \\
\hline $\mathrm{x}$ & - & - & - & - & $\mathrm{h}$ & - & - \\
\hline Ц & $\underline{t}$ & $\underline{t}$ & $\mathrm{c}$ & - & - & - & - \\
\hline ч & $\mathrm{c}$ & $\mathrm{c}$ & $\check{c}$ & ç & ç & $\mathrm{ch}$ & ç \\
\hline$\biguplus$ & - & - & $\mathrm{dž}$ & - & - & - & - \\
\hline чч & - & - & - & - & - & - & $\mathrm{c}$ \\
\hline ш & Ş & Ş & $\check{\mathrm{s}}$ & Ş & Ş & sh & Ş \\
\hline щ & şt & - & - & - & - & - & - \\
\hline ы & - & â, $\hat{\imath}$ & - & - & - & $\mathrm{y}$ & $\mathrm{i}$ \\
\hline $\mathrm{b}$ & - & $\mathrm{i}$ & - & $\mathrm{y}$ & - & - & - \\
\hline $\mathrm{b}$ & $\breve{a}$ & - & - & - & , & - & - \\
\hline э & - & $\breve{a}$ & - & - & e & $a^{\prime}$ & - \\
\hline Ю & $\mathrm{iu}$ & iu & - & - & - & - & - \\
\hline я & ia & ea, ia & - & - & - & - & - \\
\hline
\end{tabular}

\section{Висновки}

Ми проаналізували Таблицю 8 щодо відтворення спірних літер для України (згідно зі стандартом КМУ 2010):

1) $\boldsymbol{\Gamma}$ і $\boldsymbol{r}$. У п’яти із семи країн існують по два варіанти для кириличної літери $\boldsymbol{z}$ - дві з них використовують $\boldsymbol{h}$ як модифікатор, дві - Узбекистан і Казахстан - залучили діакритики - $\breve{g}$ і $\boldsymbol{g}$, одна країна взяла інший знак $-\boldsymbol{q}$.

2) $\boldsymbol{g}, \boldsymbol{ю}, \boldsymbol{\epsilon}, \ddot{i}$. Літера $\boldsymbol{\epsilon}$ існує тільки у двох абетках із семи й відтворюється за допомогою знака $\boldsymbol{e}$. Літера ж $\boldsymbol{e}$ (у цьому випадку відповідник української $\boldsymbol{\epsilon}$ у шести із семи випадках відтворюється як $\boldsymbol{e}$, тільки в Молдові $€$ варіант $\boldsymbol{i e}$. Літери ю і $\boldsymbol{я}$ існують тільки в молдовській і румунській кириличній абетках і транскодуються як $\boldsymbol{i} \boldsymbol{u}$ й $\boldsymbol{i} \boldsymbol{a}$ відповідно. Літери $\boldsymbol{i}$ в кириличних абетках досліджуваних країнах не було.

3) Жу п’яти країнах із семи передається як $\boldsymbol{j}$, у двох - Сербії та Туркменістані - як б.

4) 3 приводу й не спостерігається єдності. Ця літера транскодується як $\boldsymbol{I}$ $\boldsymbol{i}, \boldsymbol{J} \boldsymbol{j}, \boldsymbol{Y} \boldsymbol{y}, \boldsymbol{Y} \boldsymbol{y}, \boldsymbol{I} \boldsymbol{\imath}$, у двох випадках - у Румунії та Азербайджані - вона не передається.

5) $\boldsymbol{X}$ у п'яти країнах із семи передається як $\boldsymbol{h}$, інший варіант в Азербайджані та Узбекистані - це $\boldsymbol{x}$.

6) Літера $\boldsymbol{\mu}$ відтворюється тільки в Румунії, Молдові - як $t$ і і Сербії - як c. У Казахстані й Узбекистані для передачі запозичених з інших мов слів використовують сполуку $\boldsymbol{t} \boldsymbol{s}$, але в офіційному алфавіті ії немає.

7) $\boldsymbol{b}$ в Туркменістані передається як $\boldsymbol{y}$, а в Молдові як $\boldsymbol{i}$. В інших абетках такої окремої літери немає, але є діакритики, що позначають пом'якшені

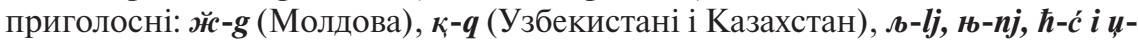
$\boldsymbol{d}$ (Сербія). 
8) Такого знака як' (anocmpoф) не існує в жодній з абеток досліджуваних країн. Якщо вважати апостроф за відповідник $\boldsymbol{\boldsymbol { z }}$, то він теж існує лише у двох країнах - у Румунії і в Узбекистані - і передається як ц̆ і' відповідно.

Тож маємо обгрунтування для визначення $2 \boldsymbol{i} r, \boldsymbol{s}, \boldsymbol{\kappa}, \boldsymbol{\epsilon}, \boldsymbol{i}, \boldsymbol{w}, \check{\boldsymbol{u}}, \boldsymbol{x}, \boldsymbol{u}, \boldsymbol{b}$, ' як найбільш спірних літер не тільки для української мови, але й для всіх постсоціалістичних країн.

Оскільки наразі нам не відомі чинники, які впливали на вибір тих чи тих літер, подальші дослідження плануємо присвятити опису взаємозв'язку між фонетикою та графікою під час переходу з кириличного на латиничне письмо постсоціалістичних країн, зокрема й України.

\section{ЛIТЕРАТУРА}

1. Вакуленко М. О. Українська латиниця як засіб представлення державної мови в міжнародному спілкуванні. Київ, 2016. URL: https://hostmaster.ua/docs/UL.html. 2. Грицеляк В. Довідник транслітерації іноземних власних назв українською мовою. Львів: НВФ «Карти і Атласи», 2009. 56 с. 3. Дідицький Б. А. О нєудобности латинскои азбуки въ письмєнности руской. Відень, 1859. 4. Дуліченко О. Писемність та літературні мови Карпатської Русі (XV-XX ст.). Ужгород: Издательство В. Падяка, 2008. 204 с. 5. Житецький П. Очеркъ литературной истории малорусскаго нарьчія въ XVII въкъ. Кіевъ: Типографія Г.Т. Корчакъ-Новицкаго, 1889. 102 с. 6. Кримський А. Нарис історії українського правопису до 1927 р. Записки Історико-Філологічного Відділу УАН. Київ. 1929. Кн. XXV. 480 с. 7. Кубайчук В. Хронологія мовних подій в Україні: зовнішня історія української мови. Київ: К. І. С., 2004. 176 с. 8. Лесюк М. П. Становлення і розвиток української літературної мови в Галичині. Івано-Франківськ: Місто НВ, 2014. 9. Маліневська Н. Фонетична система української мови XVII ст. - початку XVIII ст. і латинська графіка. Оломоуц, 2005. 125 с. 10. Міньковська I. I. Транскрибування і транслітерування: можливості і проблеми застосування в Україні. Наукові записки Вінницького держсавного педагогічного університету імені Михайла Коцюбинського. Вінниця: ТОВ «Фірма «Планер», 2015. Вип. 22. С. 270-286. 11. Міньковська І. І. Букви і політика: українські латиниці у IX-XX століттях. IX Симпозіум україністів Центральної та Східної Європи. Оломоуц, 2018. URL: https://goo.gl/y3QCL7. 12. Німчук В. Мовознавство на Україні у XIV - XVII ст. Київ: Наукова думка, 1985. 190 с. 13. Огієнко I. Історія української літературної мови. Упоряд., авт. іст.-біогр. нарису та приміт. M. С. Тимошик. Київ: Наша культура і наука, 2001. 440 c. URL: http://litopys.org.ua/ ohukr/ohu08.htm. 14. Пилипенко С. В. Odvertyj lyst do vsix, xto cikavut'sja cijeju spravoju. Червоний шлях. Вип.6-7. Харків, 1923. С. 267-268. 15. Руднищький Я.-Б.А. Чужомовні транслітерації українських назв: Інтернаціональна, англійська, французька, німецька, еспанська й португальська. Праці відділу назвознавства Інституту родо- й знаменознавства. Вип. 1. Серія: бібліографічна й загальна, ч. 1. 1948. С. 1-6. 16. Сімович В.І. Праці у 2 т. (упоряд. Л. Ткач). Книги - ХХІ. Чернівці, 2005. 17. Шахматов О., Кримський А. Нариси з історії української мови та хрестоматія з пам'ятників письменської старо-українщини XI-XVIII в.в. Київ: Видавниче Т-во «ДРУКАР», 1922. 182 с. 18. Шашкевич М. С. Повне зібрання творів (за ред. М. Шалати). Дрогобич: Коло, 2012. 19. Drahomanov M. П. Marija maty Isusowa. Wirszy Tarasa Szewczenka z uwahamy M. Drahomanova. Женева, 1882. 20. Dyer D. L. The Romanian Dialect of Moldova: A Study in Language and Politics. Lewiston, NY: Edwin Mellen Press, 1999. 21. Dyer D. L. Studies 
in Moldovan. New York: Columbia University Press. East European Monographs, 1996. 22. Loziński J. Ruskoje wesile. Перемишль: Typografija Władyczna, 1835. 23. Subotić L., Sredojević D., Bjelaković I. Fonetika i fonologija: Ortoepska i ortografska norma standardnog srpskog jezika (Serbian). Filozofski fakultet: Novi Sad, 2012. 24. Tengri News. Новый вариант казахского алфавита на латинице утвердил Назарбаев, 2018. URL: https://tengrinews. kz/kazakhstan_news/novyiy-variant-kazahskogo-alfavita-latinitse-utverdil-338010/. 25. Tengri News. Обновленный казахский алфавит: отсутствие буквы Ц объяснил разработчик, 2018. URL: https://tengrinews.kz/kazakhstan_news/obnovlennyiy-kazahskiyalfavit-otsutstvie-bukvyi-ts-338031/. 26. Газета.UZ. Узбекский алфавит ждет улучшение, 2018. URL: https:/www.gazeta.uz/ru/2018/11/06/alphabet/. 27. Законодательная Палата Олий Мажлиса Республики Узбекистан. О введении узбекского алфавита, основанного на латинской графике, 1993. URL: http://parliament.gov.uz/ru/laws/ adopted/82/3532. 28. Исмаилова Г. Г. К истории азербайджанского алфавита. Вопросы совершенствования алфавитов тюркских языков СССР. Москва: Наука, 1972. С. $28-$ 40. 29. Пиотровский Р. Г. Славяно-молдавские языковые отношения и вопросы национальной специфики молдавского языка. Вопросы молдавского языкознания. Москва: Издательство Академии Наук СССР, 1953. С. 135-149. 30. Реформатский А. А. Транслитерация русских текстов латинскими буквами. Вопр. языкознания. № 5, 1960. С. 96-103. 31. Сергиевский М. В. Материалы по изучению живых молдавских говоров на территории СССР. Учёные записки Института языка и литературы. Т. I, 1927. С. 71-95. 32. Шустек 3. Румынские надписи на бумажных деньгах и их орфография. Крыніцазнауства і спецыяльныя гістарычныя дысиылліны: навук. зб. Вып. 4. Мінск: БДУ, 2008. 231 с. 33. Чарыяров Б. Из истории туркменского алфавита (рус.). Вопросы совершенствования алфавитов тюркских языков СССР. Москва: Наука, 1972. С. 149156. 34. Щерба Л. В. Транслитерация латинскими буквами русских фамилий и географических названий. Москва. 1940. № 3. С. 119.

\section{REFERENCES}

1. Vakulenko, M. O. Ukraiyinska latynytsia yak zasib predstavlennia derzhavnoiyi movy u mizhnarodnomy spilkuvanni [Ukrainian Latin as a means of representing the state language in international communication]. Kyiv, 2016. Retrieved from https://hostmaster. ua/docs/UL.html [in Ukrainian]. 2. Hrytseliak, V. Dovidnyk transliteratsiyi inozemnykh vlasnykh nazv ukrayinskoiu movoiu [Directory of transliteration of foreign proper names in Ukrainian]. Lviv: NVF «Karty i Atlasy», 2009. 56 p. [in Ukrainian]. 3. Didytskyi, B. V. O nieudobnosti latinskoi azbuki v pismennosti ruskoi [About the inconvenience of the Latin alphabet in Rus writing]. Viden, 1859. 4. Dulichenko, O. Pysemnist ta literaturni movy Karpatskoyi Rusi (XV-XX st.) [Written and literary languages of the Carpathian Rus (XV-XX centuries)]. Uzhgorod: Izdatelstvo V. Padiaka, 2008. 204 p. [in Ukrainian]. 5. Zhytetskyi, P. Ocherk litaraturnoi istoriyi maloruskaho narechiia v XVII viekie [An Essay on the Literary History of Little Russian Literature in the XVII Century]. Kiev: Typohrafiia H.T. KorchakNovitskaho, 1889. 102 p. 6. Krymskyi, A. Narys istoriyi ukrayinskoho pravopysu do 1927 r. [Essay on the history of Ukrainian spelling until 1927] Zapysky Istoryko-Filolohichnoho Viddilu UAN. Kyiv. 1929. Kn. XXV. 480 p. [in Ukrainian]. 7. Kubaichuk, V. Khronolohiia movnykh podii v Ukrayini: zovnishnia istoriia ukrayinskoyi movy [The chronology of linguistic events in Ukraine: the foreign history of the Ukrainian language]. Kyiv: K. I. S., 2004. 176 p. [in Ukrainian]. 8. Lesiuk, M. P. Stanovlennia i rozvytok ukrayinskoyi literaturnoyi movy v 
Halychyni [Formation and development of the Ukrainian literary language in Galicia]. Ivano-Frankivsk: Misto NV, 2014 [in Ukrainian]. 9. Malinevska, N. Fonetychna systema ukrayinskoyi movy XVII st. - pochatku XVIII st. i latynska hrafika [Phonetic system of the Ukrainian language in XVII- XVIII centuries and Latin graphics]. Olomouts, 2005. 125 p. [in Ukrainian]. 10. Minkovska, I. I. Transkrybuvannia i transliteruvannia: mozhlyvosti i problemy zastosuvannia v Ukrayini [Transcribing and transliterating: opportunities and problems in Ukraine]. Naukovi zapysky Vinnytskoho derzhavnoho pedahohichnoho universytety imeni Mykhaila Kotsiubynskoho. Vinnytsia: TOV «Firma «Planer», 2015. Vyp. 22. P. 270-286. [in Ukrainian]. 11. Minkovska, I. I. Bukvy i polityka: ukrayinski latynytsi u IX-XX stolittiakh [Letters and politics: Ukrainian Latins in 19-20 centures]. IX Symposium ukrayinistiv Tsentralnoyi ta Skhidnoyi Yevropy. Olomouts, 2018. Retrieved from https://goo.gl/y3QCL7 [in Ukrainian]. 12. Nimchuk, V. Movoznavstvo na Ukrayini u XIV - XVII st. [Linguistics in Ukraine in the XIV-XVII centuries]. Kyiv: Naukova dumka, 1985. 190 p. [in Ukrainian]. 13. Ohiienko, I. Istoriia ukrayinskoyi literaturnoyi movy [History of the Ukrainian literary language]. Kyiv: Nasha kultura i nauka, 2001. 440 p. Retrieved from http://litopys.org.ua/ ohukr/ohu08.htm [in Ukrainian]. 14. Pylypenko, S. V. Odvertyj lyst do vsix, xto cikavut'sja cijeju spravoju [A frank letter to anyone interested in this business]. Chervonyi shlyakh. Vyp.67. Kharkiv, 1923. P. 267-268 [in Ukrainian Latin]. 15. Rudnytskyi, Ya.-B.A. Chuzhomovni transliteratsiyi ukrayinskykh vlasnykh nazv: internatsionalna, anhliiska, frantsuzka, nimetska, espanska i portuhalska [Foreign language transliteration of Ukrainian names: International, English, French, German, Spanish and Portuguese]. Pratsi viddilu nazvoznavstva Instytutu rodo- $i$ znamenoznavstva. Vyp. 1. Seriya: bibliohrafichna i zahalna, ch. 1. 1948. P. 1-6 [in Ukrainian]. 16. Simovych, V. I. Pratsi u dvokh tomakh [Works in 2 t.]. Knyhy - XXI. Chernivtsi, 2005 [in Ukrainian]. 17. Shakhmatov, O., Krymskyi A. Narysy z istoriyi ukrayinskoyi movy ta khrestomatiia z pamiatnykiv pysmenskoyi staro-ukrayinshchyny XI-XVIII v. [Essays on the history of the Ukrainian language and textbooks from the monuments of the old Ukrainian writing of the XI-XVIII centuries]. Kyiv: Vydavnyche T-vo «DRUKAR», 1922. 182 p. [in Ukrainian]. 18. Shashkevych, M. S. Povne zibrannia tvoriv [A complete collection of works]. Drohobych: Kolo, 2012 [in Ukrainian]. 19. Drahomanov, M. П. Marija maty Isusowa. Wirszy Tarasa Szewczenka z uwahamy M. Drahomanova [Taras Shevchenko's poems with comments from Mykhailo Drahomanov]. Zheneva, 1882 [in Ukrainian]. 20. Dyer, D. L. The Romanian Dialect of Moldova: A Study in Language and Politics. Lewiston, NY: Edwin Mellen Press, 1999. 21. Dyer, D. L. Studies in Moldovan. New York: Columbia University Press. East European Monographs, 1996. 22. Loziński, J. Ruskoje wesile [Ukrainian wedding]. Peremyshl: Typografija Władyczna, 1835 [in Ukrainian Latin]. 23. Subotić, L., Sredojević D., Bjelaković I. Fonetika i fonologija: Ortoepska i ortografska norma standardnog srpskog jezika (Serbian). Filozofski fakultet: Novi Sad, 2012 [in Serbian]. 24 Tengri News. Novyi variant kazakhskoho alfavita na latinitse utverdil Nazarbaiev [A new version of the Kazakh alphabet in Latin was approved by Nazarbayev], 2018. Retrieved from https://tengrinews.kz/ kazakhstan_news/novyiy-variant-kazahskogo-alfavita-latinitse-utverdil-338010/ [in Russian]. 25 Tengri News. Obnovliennyi kazakhskii alfavit: otsutstviie bukvy Ц obiasnil razrabotchik [Updated Kazakh alphabet: the developer explains the absence of the letter Ц], 2018. Retrieved from https://tengrinews.kz/kazakhstan_news/obnovlennyiy-kazahskiy-alfavitotsutstvie-bukvyi-ts-338031/ [in Russian]. 26. Gazeta.UZ. Uzbekskii alfavit zhdiet uluchsheniie [The Uzbek alphabet is waiting for improvement], 2018. Retrieved from https:// www.gazeta.uz/ru/2018/11/06/alphabet/ [in Russian]. 27. Zakonodatelnaia Palata Olii 
Mazhlisa Respubliki Uzbekistan. O vvedeniyi uzbekskoho akfavita, osnovannoho na latinskoi hrafike [About the implementation of the Uzbek alphabet based on the Latin graphic], 1993. Retrieved from http://parliament.gov.uz/ru/laws/adopted/82/3532 [in Russian]. 28. Ismailova, H.H. K istoriyi azerbaidzhanskoho alfavita [About the history of Azerbaijan language]. Voprosy sovershenstvovaniia alfavitov tiurkskih yazykov SSSR. Moskva: Nauka, 1972. P. 28-40 [in Russian]. 29. Piotrovskii, R. H. Slavyano-moldavskiie yazykovyie otnosheniia i voprosy natsionalnoi spetsyfiki moldavskoho yazyka [Slavic-Moldavian language relations and issues of national specificity of the Moldavian language]. Voprosy moldavskoho yazykoznaniia. Moskva: Izdatelstvo Akademii Nauk SSSR, 1953. P. 135-149 [in Russian]. 30. Reformatskii, A. A. Transliteratsiia russkih tekstov latinskimi bukvami [Transliteration of Russian texts in Latin letters]. Voprosy yazykoznaniiia. № 5, 1960. P. 96-103 [in Russian]. 31. Serhiievskii, M. V. Materialy po izucheniiu zhyvykh moldavskikh hovorov na territoriyi SSSR [Materials for the study of living Moldovan dialects in the USSR]. Uchienyie zapiski Instituta yazyka i literatury. T. I, 1927. P. 71-95 [in Russian]. 32. Shustek, Z. Rumynskiie nadpisi na bumazhnykh denhakh i ikh orfohrafiia [Romanian inscriptions on paper money and their spelling]. Minsk: BDU, 2008. 231 p. [in Russian]. 33. Charyiarov, B. Iz istoriyi turkmenskoho alfavita [From the history of the Turkmen alphabet]. Voprosy sovershenstvovaniya alfavitov tiurkskikh SSSR. Moskva: Nauka, 1972. P. 149-156. [in Russian]. 34. Shcherba, L. V. Transliteratsiya latinskimi bukvami russkikh familii i heohraficheskikh nazvanii [Transliteration in Latin letters of Russian surnames and geographical names]. Moskva. 1940. № 3. P. 119. [in Russian].

Міньковська Ірина Ігорівна - аспірантка кафедри української мови, Харківський національний педагогічний університет імені Г. С. Сковороди; вул. Валентинівська, 2, Харків, 61168, Україна.

Tel.: +380661889975 .

E-mail: iryna.minkovska@gmail.com.

https://orcid.org/0000-0003-0245-2361.

Minkovska Iryna Ihorivna - Postgraduate Student, Ukrainian Language Department, H.S. Skovoroda Kharkiv National Pedagogical University; Valentynivska Str., 2, Kharkiv, 61168, Ukraine. 